\title{
Paula Przysada
}

Wroclaw University of Economics and Business

e-mail: paula.przysada@ue.wroc.pl

ORCID: 0000-0002-5136-7414

\section{CULTURAL DIVERSITY IN THE CONSTRUCTION OF INCENTIVE SYSTEMS IN ENTERPRISES - LITERATURE REVIEW}

RÓŻNORODNOŚĆ KULTUROWA

A KONSTRUKCJA SYSTEMÓW

MOTYWACYJNYCH W PRZEDSIĘBIORSTWACH PRZEGLĄD LITERATURY

DOI: 10.15611/e21.2019.2.07

JEL Classification: F23, M50, O15

Summary: The aim of the work is to emphasize the importance of cultural diversity in the process of creating motivational systems. Therefore, selected definitions of motivation and incentive systems are collected and discussed in the article. The reason for their functioning in enterprises is to motivate employees and improve their work with financial and non financial incentives. Motivation is defined as the internal state of human being, which consists of feeling the lack of meeting the needs. In turn, motivating is an element of management that consists of using motivators in such a way that they ensure employees' engagement for the organization's aims, encourage employees to raise their qualifications and give them job satisfaction.This article also defines formal and informal institutions that are relevant to the operation of incentive systems. This work is based on literature review.

Keywords: incentive systems, motivators, international enterprises.

Streszczenie: Celem pracy jest podkreślenie znaczenia różnorodności kulturowej w procesie tworzenia systemów motywacyjnych. W związku z tym w artykule zebrano i omówiono wybrane definicje motywacji oraz systemów motywacyjnych. Powodem ich funkcjonowania w przedsiębiorstwach jest motywowanie pracowników i doskonalenie ich pracy przy użyciu bodźców natury finansowej i niefinansowej. Motywacja to wewnętrzny stan człowieka, który polega na odczuwaniu pewnych potrzeb, które człowiek chce zaspokoić. Natomiast motywowanie to element zarządzania opierający się na takim wykorzystywaniu motywatorów, by zapewniały zaangażowanie pracowników na rzecz sukcesu organizacji, zachęcały do podnoszenia kwalifikacji i dawały satysfakcję z pracy. W artykule zdefiniowano również instytucje formalne i nieformalne, które są istotne z punktu widzenia działania systemów motywacyjnych. Praca powstała na podstawie studiów literaturowych.

Słowa kluczowe: system motywacyjny, motywatory, przedsiębiorstwa międzynarodowe. 


\section{Introduction}

Modern enterprises around the world are under the pressure of how:

- to become more effective,

- to decrease their costs,

- to increase revenue,

- to improve the employees' performance to adapt to changes in the environment.

The aim of this work is to describe the importance of cultural diversity while creating the incentive system whose goal is to motivate employees and improve their work. Effectiveness of the company could be achieved basing on many aspects, but the primary one is motivating employees.

A question which is frequently asked is how to motivate people properly and encourage them to grow within their company. Competent and motivated employees are one of the strongest competitive advantages of every enterprise.

Human capital is treated as a production factor that cannot be easily copied or imitated. Therefore, different research on motivation is becoming very popular at present. A lot of components should be taken into account to create a wellfunctioning incentive system. One of them is the company's organisational culture [Czetwertyński 2019]. R. Deshapande and R. Parasurman describe it as the set of unwritten rules (often perceived subconsciously) that fulfil the gap between what is unwritten and what is really going on in the organisation [1987]. According to Hofstede the organisational culture could be divided into five different dimensions and this model offers specific guidelines on the construction of the incentive system. This division includes:

- individualism and collectivism,

- power distance,

- uncertainty avoidance,

- masculinity and femininity,

- long-term orientation and short-term orientation.

Informal institutions, such as cultural factors or informal social rules, also play a significant role in creating the unwritten behaviour models among employees in the company [Sukiennik 2015]. An effectively functioning institutional system is conducive to economic development [Sukiennik et al. 2017] and at the same time increases the effectiveness of an individual company that operates on the market. Moreover, formal institutions, such as law, constitution and regulations determine business operations and should be also taken into account [Sukiennik 2017].

Cultural differences play an important role in understanding employees' needs and justifying the degree of job satisfaction. Employees from different foreign countries have different perceptions. Building the incentive system requires understanding which factor is the most effective one to motivate employees. Nowadays, there are many international corporations which employ people from different countries. 
Therefore, multicultural management is really significant in organisations which employ staff from different cultural backgrounds.

The first chapter of this work includes the description of the incentive system and motivation. This part of work includes various definitions of these phenomena and the explanation of the difference between the two. The second chapter deals with the subject of financial and non-financial motivators that influence the effectiveness of employees' work. The third chapter consists of the description of incentive systems' instances dependent on the geographical location and cultural differences. This work is based on the literature and various articles focusing on the importance of the employees' motivation system in the company activities.

\section{Incentive system and motivation}

Nowadays, the most valuable asset of enterprises is human capital. Employees are the driving force of the company's success. Hence, human capital is the main source of the competitive advantage of a particular company [Ali et al. 2009]. Therefore, it is crucial to keep the best employees in the company [Alamzeb 2012]. The incentive system needs appropriate methods which use specific motivators to influence the employees' activities.

In literature there exist various concepts of motivation and motivation process. People often confuse both terms which in reality have different meanings. Motivating is a process understood as an interaction between human motivation and selected stimuli. It is a state of tension in a given person to perform a particular action responding to a specific need. This need is a trigger to motivate staff and cause employee`s reaction [Zielak 2012].

In the literature, a lot of definitions of human motivation can be found that allows better understanding of its essence. Incentives should be selected according to individual needs because they affect people differently [ Armstrong 2005]. It should be emphasised that various forms of motivation influence employee's behaviour differently. However, such an individual treatment is impossible in international companies which employ workforce from different cultural regions. To create the incentive system they take average values of a specific category of needs. These average values characterize a given organizational culture and are accepted by most, but not all employees.

One can presume that in large companies, especially culturally diverse international corporations, the "averaging" procedure can mean the occurrence of significant differences between what is important for a particular individual and this average. Due to it the effectiveness of the incentive system can be flawed [Zielak 2012]. According to M. Armstrong, motivation is goal-oriented behaviour. People are motivated when they expect the course of action to lead them to a goal and a valuable reward-the one that will meet their needs [Armstrong 2005]. P. Sikavica, F. Bahtijarević-Šiber and N. Pološki-Vokić define motivation similarly as a process 
that initiates and directs actions towards achieving both individual and corporate goals [Sikavica et al. 2008].

M. Matsie defines motivation basing on psychological aspect of human nature and describes it as a host of psychological processes that culminate in an individual's desire and intentions to behave in a particular way [2008]. Also Adeoye bases its definition on this field of science, adding that those processes cause the arousal, direction and persistence of voluntary actions that are goal-directed [Adeoye 2001]. Other researchers are supporters of the same theory that motivation is the driving force of employees' actions that influence energy and direct behaviour and is considered to be goal-oriented (for example [Ahlstrom, Bruton 2010]). Therefore, motivation could be characterised as a factor that determines employee's effectiveness in achieving particular enterprise results. A proper activity of the incentive system needs internal motivation process. Sikorski considers it as the process accompanying the exchange between the employee and the organization [Sikorski 2004]. An employee who wants to meet certain needs must pay their entity a specific own contribution. Therefore, motivation is understood as the readiness to act to achieve the desired goals. An employee begins to act when he/she experiences unpleasant tension resulting from a sense of lack of something [Sikorski 2004]. Needs are states characterized by failure to meet certain conditions desired by humans and necessary for them to carry out social roles. The hierarchy of needs is presented by A. Maslow as a motivational theory in psychology comprising a five-tier model of human needs. This theory is very important to create incentive systems in enterprises. Regardless which benefit is offered to an employees, it will fall under Maslow's pyramid categories.

\section{Types of pay and non-pay motivators}

According to Maslow, people have some needs because they are social and psychological entities and these needs are common for human beings. He assumes that people work more effectively if they are provided with the right incentives to meet their needs that can be properly ranked (see Figure 1). On this basis, it can be presumed that a person undertakes activities, including professional work, when the unfulfillment of a certain state is felt. Maslow's division could be very helpful to understand the needs of employees. These needs are divided into lower-higher level. First of all, once these basic needs are satisfied to a reasonable degree, an individual becomes aware of higher-level needs. This can result in better human management because it determines what can be done to satisfy workers. Moreover, there exists the relationship between their satisfaction level and the effectiveness of their work, which will increase in this case. Secondly, there are differences between people's behaviours and their needs. Even if everyone has the same needs, for example biological ones, their position in the hierarchy of needs could be different.

To sum up there is no difference between particular needs but there is one in the degree of satisfaction people get from work. This also shows the importance 


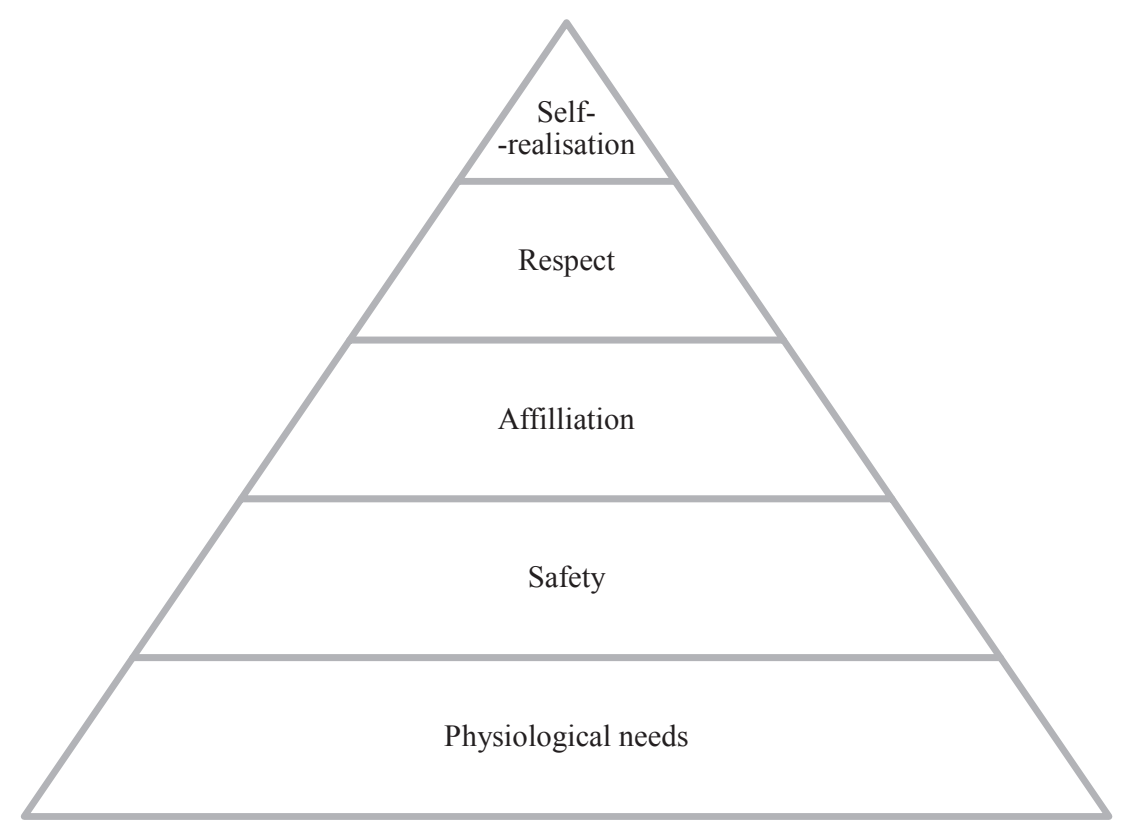

Figure 1. The structure of needs by A. Maslow

Source: [Kostera et al. 2007].

of knowledge of informal institutions in human capital management. Knowing the employees' needs and the level of their satisfaction, the choice of instruments used in the motivating processes should be discussed. These instruments are divided into financial and non-financial motivators.

\subsection{Wage as a component of remuneration scheme}

Wage is treated as a classical motivator for every employee that encourages effective work and improvement of their professional skills. It is the easiest and the most efficient way of communication between employers and employees. Wage is a guide of the employees 'value for the company. The importance of this kind of motivation is determined by individual needs and expectations [Wachowiak, Stużyńska 2008]. The level of wage determines the standard of living, achievements of employees, however it is an imperfect method of employee's valuation [Armstrong 2005]. M. Kostera treats wages as one of the basic forms of remuneration. An employee receives a certain amount of money for their work and the accompanying effort. This helps them fulfill their basic physiological needs like food, clothing etc. [Kostera 2010].

The basic forms of renumeration could include: subsidised rent and bonuses which can be divided into individual or team ones depending on the results of the company [Kopertyńska 2007]. Furthermore, the legislator imposes on an employer 
the obligation to determine and apply the remuneration regulations in companies employing at least 20 employees. The renumeration system has to include such components as additional remuneration for overtime and night work. Properly constructed renumeration scheme should take into account the incentive system and remuneration components that guarantee correct tasks execution (see Table 1).

Table 1. The components of the renumeration system

\begin{tabular}{|l|l|}
\hline \multicolumn{1}{|c|}{ Task } & $\begin{array}{c}\text { The pay component that guarantees } \\
\text { the execiution of the task }\end{array}$ \\
\hline Acquisition and retention of valuable employees & Basic wage \\
\hline Motivating to achieve company's goals & Bonus \\
\hline $\begin{array}{l}\text { Motivating for effective implementation of tasks assigned } \\
\text { to particular position }\end{array}$ & Bonus \\
\hline $\begin{array}{l}\text { Motivating for creativity, innovation, activity, } \\
\text { entrepreneurship and additional activities }\end{array}$ & Bonus \\
\hline Motivating to take more responsibility & Basic wage, bonus \\
\hline Motivating for team work & Team bonus \\
\hline Motivating to competence development & Basic wage \\
\hline Motivating for honesty and loyalty to the employer & Basic wage \\
\hline
\end{tabular}

Source: [Kopertyńska 2008].

Looking at the information shown in the table it can be concluded that basic wage is important in acquiring and retaining employees, motivating them to develop new competencies, taking more responsibility and building loyalty and trust to the employer [Kopertyńska 2008]. Furthermore, one of the most significant components in the organization management is the selection of an effective set of incentives which play the role of an important motivator and should be specified in the regulations of renumeration schemes. The variable components of the remuneration system could be treated as bonuses which depend on the employee`s achievement [Kawka 2001]. The basic forms of bonuses can be divided into [Kopertyńska 2001]:

- bonuses depending on:

- individual results,

- group and team results,

- the effects achieved by the entity,

- the combination being a derivative of individual and team achievements.

- bonus related to subsidized rent:

- embedded in flat pay,

- complementary flat pay that is operating next to it.

The most frequently used formulas for combining bonuses with work effects are:

- task bonuses, depending on the degree of achievement of the goal by individual employees, team or department, 
- share bonuses, which are a kind of distribution of profits between management and employees. Benefits in this form depend on the results of the entire organisation.

Furthermore, effective bonuses require the fulfillment of numerous organisational conditions [Kawka 2001]:

- the employee evaluation system should be the most important source of information used to define the size of the bonus,

- the bonus task should be defined and assigned to the company, departments, teams, and individual employees,

- the size of the payment should be based on the set of measurable criteria,

- the management should make credible promises because employee's effort can get increased only in the long run,

- bonus criteria should be based on employee's tasks and personal abilities,

- bonus should be a benefit next to wage,

- bonus rates should be associated with an individual position of an employee,

- intervals between granting them and the results of work cannot be too long,

- in case of teamwork, group criteria should be applied first and then individual ones.

These guidelines are addressed to employees and employers and should guarantee beneficial solutions to both parties.

\subsection{Non-wage motivation}

If financial motivators are at the level desired by employees, they lose their power as an incentive. In this case the incentive system should start using non-financial stimuli. Besides, these motivators are often met with grateful acceptance by employees. These non financial motivators are granted to employees as an "extra" reward for their work. This non financial part of the motivation system is an important component of motivating in the conditions of high competitiveness on the market and allows to retain intellectual capital in the company [Szałkowski 2000]. The most frequently mentioned in professional literature non-pay incentives include [Kopertyńska 2008]:

- stock,

- shares,

- insurances,

- pension programmes,

- preferential employee loans,

- preferential rules for the provision of certain services,

- courses and postgraduate studies,

- trips, parties, business and occasional events,

- entrance passes for swimming pools, cinemas, and other entertainment facilities,

- co-financing of holidays, etc.,

- free babysitting,

- crèche, 
- gift coupons, for instance, on the occasion of Christmas,

- a business flat,

- providing portable computers for business purposes,

- company car, parking, monthly urban transport ticket,

- material prizes for original ideas.

In the opinion of a lot of researchers non financial motivators integrate employees with management faster and more effectively than other motivators, create a friendly atmosphere in the workplace and shape a positive image of a company. Non financial incentives of a motivation system should be used with appropriate financial motivators. The most frequently mentioned components of non-wage motivators are [Kopertyńska 2008]:

- recognition of employees,

- effective communication,

- expected working conditions,

- employee's development,

- respect for the employee,

- appropriate atmosphere at work.

Summing up the statement that employees' efficiency depends only on financial motivators is wrong. The accurate system of motivation should include the combination of financial and non financial incentives.

\section{Types of incentive systems}

People from China, Israel and Korea believe that achievement is the key aspect in people's working life as it meets their needs for self-improvement unlike people from Germany, the United States or Holland who have a different attitude and expectations. For them the most important value and source of motivation is having fun of work [Zhao, Pan 2017]. In this article various motivating factors have been distinguished within such countries as China, Japan and Rwanda.

In Japan it is typical to motivate people through medals, attention, and applause, but it is not a kind of distinction desired by all. Japanese companies focus on teams' or enterprises' overall goals in contrast to citizens of the United States who pay more attention to individual goals [Zhao, Pan 2017]. For the Japanese the institution of a family and community plays the major role and not the social status or prestige at work. In case of Japan some motivators are rarer in literature but have an important value for employees, for example: drinking with colleagues, personal and friendly leadership, kind atmosphere, overnight excursions, job rotation and company's sports programmes.

The quality of supervision, friendship and respect of coworkers should be included in the group of high level motivators. Japanese organisations use the principle of equality of applied motivators to make people compete and simultaneously support cooperation among them. Individuals in Japan are characterised through interpersonal 
competition, which aims to apply more desirable tasks and special options in the field of professional development. These aspects are more significant than immediate promotion or wage increase. Japanese managers try to create an environment in which all employees identify their interests with the goals of a company and they are motivated to solve problems to meet the purposes of an organisation [Taguchi 2015]. In Japan there are discrepancies between incentives depending on a kind of employment (permanent vs. temporary). Generally employees working on the permanent basis gain more rewards in terms of wage than the temporary workers [Ahammad et al. 2016] .

Chinese employees represent a different approach because they are focused on work. They are work-oriented and they spend a lot of time in a company, including work at night or overtime. Even if they are overtired, they must finish their work on time. The needs of Chinese employees include four levels [Figure 2].

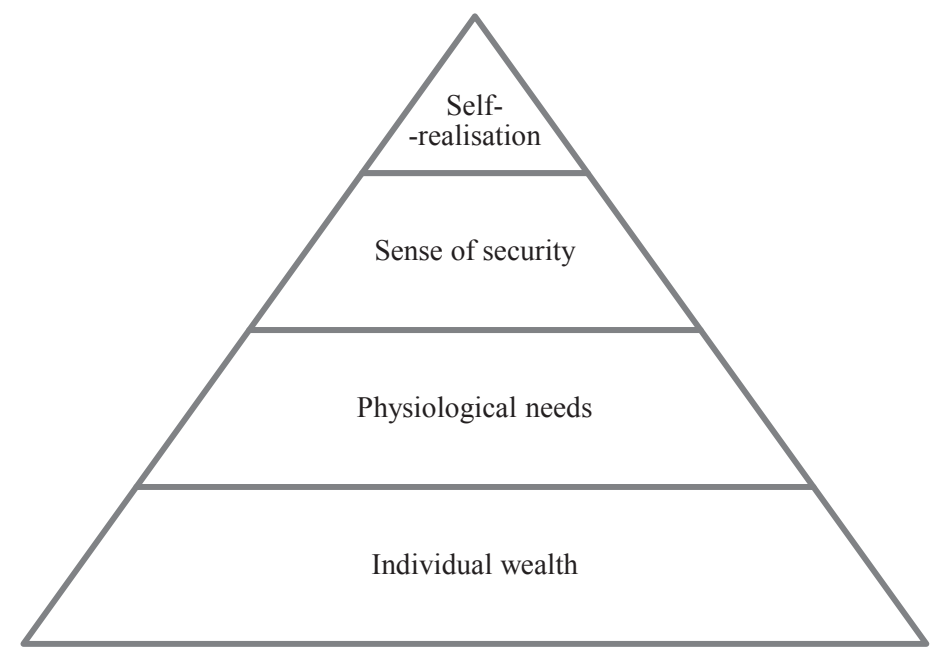

Figure 2. The pyramid of Chinese employees' needs

Source: [Jamal 2015].

This hierarchy of needs shows the significance of cultural differences. Even if the needs are almost similar to those presented in the Maslow's theory, they are located at different levels in the hierarchy of needs. Moreover, it is important for ordinary employees in China to become members of the workgroup [Jamal 2015]. At the same time money is also an important incentive. Historically Chinese employees were more saving oriented due to living conditions. However, merit recognition is a significant need of Chinese employees and therefore there is constant competition in order to get prized by the employers [Farndale, Murrer 2015].

In the incentive system in Rwanda the most significant motivators for employees are an adequate pay and recognition for work-based achievements [Nimusima, 
Tumwine 2016]. On the other hand, non-financial motivators such as health insurance and a good working atmosphere are needed for effective work. Employees in Rwanda pay particular attention to the following issues, which should be included in the proper working incentive system [Nimusima, Tumwine 2016]:

- reward and appreciation of hard work by employees by increasing wages, overtime payment, providing refreshments, lunch, recognition gifts, etc.,

- application of negative motivation for poor performers by reducing their wages, demotion, external transfers, etc. as it is in the case of incentives to encourage them to perform better,

- involvement of employees in the decision making process,

- increase of the responsibility for information sharing,

- positive reinforcement and treatment of all staff members in a fair manner,

- reduction of the gap in the remuneration between the executive committee and implementation committee,

- creation of adequate training facilities for workers.

Rwanda's employees are motivated to work if they are assigned a job according to their skills. When they are given appropriate tasks in which they are well trained, their work is more effective. Furthermore, hardworking, talented, and ambitious employees should be given opportunities and space to develop their potential. A motivated employee performs better, provided that supervisors understand their role and provide clear mentoring. To retain high skilled workers it is important to ensure safe and conducive environment. The need for professional development is a significant motivator for ambitious employees' so the opportunity to take part in training programmes that help improve their skills and knowledge should be included in the incentive system.

The results of this study indicate that a company should pay more attention to the proper implementation of factors motivating employees to fully use their potential and maintain a competitive advantage. An effective incentive system should be based on employees' cultural background. Although every human has similar needs, the way to meet them depends on informal institutions such as religion, rules, norms and culture, etc.

\section{Conclusions}

Enterprises create their own individual incentive systems adapted to their financial capabilities but also employee's expectations. They vary according to different cultural backgrounds. Every company strives to motivate employees to work harder. Human resources can be considered in terms of present and future needs. A company can invest in development and training of employees to achieve benefits and use the potential of trained people. The possibility of participating in various types of workshops, courses or undertaking studies may also be a mutual benefit. These incentives should be treated as the most important factors that encourage employees 
to put effort to their work and do their duties assigned to them more effectively. The incentive and reward system helps employers to motivate people in such a way that they use their capabilities to make work more efficient [Gana, Bababe 2011]. This policy results in higher profits of companies. On the other hand, the lack of suitable incentive system influences the performance of hard-working people because their productivity at work decreases. In other words, the chance to achieve the goals and improve the effectiveness falls [Palmer 2012]. People that manage international teams should concentrate more on observing and discovering the needs of foreign employees to create the most suitable incentive mechanism. This helps achieve better results, generate enthusiasm of employees for their work and improve performance of an organisation.

\section{References}

Adamus W., 2005, Motywacyjna teoria ważności potrzeb, celów i wartości, Wybrane aspekty zarzadzania organizacjami, Oficyna Wydawnicza AFM, Kraków.

Adeoye A.O., 2001, Contemporary Issues in Human Resources Management and Organisational Behaviour, Pumark Publishers, Lagos.

Ahammad M.F., Tarba, S.Y., Liu, Y., Glaister K.W., 2016, Knowledge transfer and cross-border acquisition performance: The impact of cultural distance and employee retention, International Business Review, Volume 25, Issue 1.

Alamzeb A., 2012, Compensation methods and employees' motivation (with reference to employees of National Commercial Bank Riyadh), International Journal of Human Resource Studies, Vol. 2, No. 3.

Ahlstrom D., Burton G., 2010, International management: Strategy and culture in the emerging world. Mason, OH: South-Western Cengage Learning.

Ali R., Shakil Ahmed M., 2009, The impact of reward and recognition programs on employee's motivation and satisfaction: An empirical study, International Review of Business Research Papers, Vol. 5, no. 4.

Armstrong M., 2005, Zarzadzanie zasobami ludzkimi, Oficyna Ekonomiczna, Dom. Wydawniczy ABC, Kraków.

Art. 77, 151, Ustawa Kodeks Pracy, Dz. U. 1974, Nr 24, poz. 141.

Borkowska S., 1985, Systemy motywowania w przedsiębiorstwie, PWN, Warszawa.

Czetwertyński S., 2019, Morfologia nieautoryzowanego kopiowania, Wydawnictwo Uniwersytetu Ekonomicznego we Wrocławiu, Wrocław.

Deshapande R., Parasurman R., 1987, Linking corporate culture to strategic planning, Business Horizons, 29(3).

Farndale E., Murrer I., 2015, Job resources and employee engagement: A cross-national study, Journal of Managerial Psychology, no. 30(5).

Gana A.B., Bababe F.B., 2011, The Effects of Motivation on Workers Performance (a case study of Maiduguri Flour Mill Ltd. Borno State), Nigeria., Continental J. Social Sciences, 4 4(2).

Heller R., 2000, Motywowanie pracowników, Wiedza i życie, Warszawa.

Jamal M., 2015, Job stress and employee well-being: A cross-cultural empirical study, International Journal of Stress Management, 6.

Kawka T., 2001, Wynagradzanie pracowników, Oficyna Ekonomiczna, Kraków. 
Kopertyńska W., 2001, Zmiana podejścia do motywowania w praktyce polskich przedsiębiorstw, Prace Naukowe Akademii Ekonomicznej we Wrocławiu nr 916, Wrocław.

Kopertyńska M.W., 2007, Motywowanie pracowników sfery produkcyjnej-doświadczenia badawcze, Dwumiesięcznik Zarządzanie Zasobami Ludzkimi, 3-4/2007.

Kopertyńska M.W., 2008, Motywowanie pracowników. Teoria i Praktyka, Agencja Wydawnicza PLACET, Warszawa.

Kostera M., 2010, Zarzadzanie personelem, Polskie Wydawnictwo Ekonomiczne, Warszawa.

Kostera M., Kownacki S., Szumski A., 2007, Zachowania organizacyjne: motywacja, przywództwa, kultura organizacyjna, [in:] A.K. Koźmiński, W. Piotrkowski (eds.), Zarządzanie: teoria i praktyka, PWN, Warszawa.

Leśniewski A., Berny J., 2012, Motywowanie placowe i pozapłacowe w przedsiębiorstwie - ujęcie teoretyczne, Zeszyty Naukowe Uniwersytetu Przyrodniczo-Humanistycznego w Siedlcach. Seria: Administracja i Zarządzanie, no. 17 (90) (2011), pp. 97-109.

Matsie M., 2008, The impact of motivation on employee performance at level one district hospitals, with special reference to Metsimaholo District Hospital in Sasolburg, North-West University.

Michalczyk W. (ed.), 2009, Wybrane problemy gospodarki światowej pierwszej dekady nowego wieku, Uniwersytet Ekonomiczny we Wrocławiu, Wrocław.

Mierzwińska L., Tabisz J., Motywacja i rozwój pracowników na przykładzie przedsiębiorstwa x, [in:] P. Lenik (ed.), Różnorodność zastosowań badań naukowych w teorii i praktyce zarzadzania, Prace Naukowo-Dydaktyczne, zeszyt 72, https://www.pwsz.krosno.pl/gfx/pwszkrosno/pl/defaultopisy/1155/5/1/11._motywacja_irozwoj_pracownikow_na_przykladzie_przedsiebiorstwa_x.pdf (accessed: 02.04.2020).

Nimusima P., Tumwine J.F., 2016, Assessing the Relationship between Employee Motivation and Productivity in Nyagatare District in Rwanda, East Africa Research Papers in Business, Entrepreneurship and Management, no. 2.

Palmer W., 2012, Incentive and disincentive: Will they affect performance, Journal of Business and Management, 14(3).

Penc J., 2001, Strategiczny system zarządzania, Agencja Wydawnicza PLACET, Warszawa.

Prugar K., Tabisz J., 2016, Analiza systemu motywacyjnego na przykładzie Centrum Dystrybucyjnego Eurocash, Uniwersytet Przyrodniczo - Humanistyczny w Siedlcach.

Quinn R., Faerman E., Thompson M.P., McGrath M.R., 2007, Profesjonalne zarzadzanie, PWE, Warszawa.

Sikavica P., Bahtijarević-Šiber F., Pološki-Vokić N., 2008, Temelji menadžmenta, Školska knjiga, Zagreb.

Sikorski Cz., 2004, Motywacja jako wymiana - modele relacji między pracownikami a organizacja, Wydawnictwo Difin S.A, Warszawa.

Sukiennik J., 2015, Państwowa regulacja rynku wyrobów tytoniowych: ścieżka rozwoju regulacji, Prace Naukowe Uniwersytetu Ekonomicznego we Wrocławiu, nr 405, Instytucje w teorii i praktyce, DOI 10.15611/pn.2015.405.10.

Sukiennik J., 2017, Path dependence-proces przeksztatceń instytucjonalnych, Prace Naukowe Uniwersytetu Ekonomicznego we Wrocławiu, nr 493, DOI 10.15611/pn.2017.493.12.

Sukiennik J., Dokurno Z., Fiedor B., 2017, System instytucjonalnej równowagi a proces zmian instytucjonalnych z perspektywy zrównoważonego rozwoju, Ekonomista, $\mathrm{nr} 2$.

Szałkowski A., 2000, Wprowadzenie do zarzadzania personelem, Wydawnictwo Akademii Ekonomicznej w Krakowie, Kraków.

Taguchi Y., 2015, Factors forming work motivation in Japan, Procedia Manufacturing, Volume 3, pp. 717-722.

Wachowiak P., Stużyńska M., 2008, Podstawy zarządzania, Oficyna Wydawnicza SGH, Warszawa. 
Zaccheaus Olonade Z., Boyede M., 2019, Job incentives and career knowledge as predictors of workers. Job performance among employees of Transmission Company of Nigeria (TCN), Research on Humanities and Social Sciences, Vol. 9, No.14.

Zhao B., Pan Y., 2017, Cross-cultural employee motivation in international companies, Journal of Human Resource and Sustainability Studies, no. 05.

Zielak P., 2012, Skuteczność narzędzi motywowania a różnorodność kulturowa, Zarządzanie Zasobami Ludzkimi, nr 5. 